\title{
ОСОБЛИВОСТІ ПРОЦЕСУ МЕДІАСОЦІАЛІЗАЦІЇ В УМОВАХ СУЧАСНОГО МЕДІАПРОСТОРУ
}

У статті розглядаються характерні особливості сучасного медіапростору та основні аспекти медіасочіалізаиії особистості. На основі аналізу психолого-педагогічної літератури розкриваємо сутність понять «медіа» та «медіасоиіаліфзачія», використовуємо їх у дослідженні як основу для характеристики впливу на формування особистості. Охарактеризуємо основні характерні особливості постінформаційного суспільства.

Спираючись на наукові дослідження вітчизняних та європейських науковців, було трунтовно проаналізовано поняття та особливості сучасного медіапростору. Також було виокремлено декілька наукових підходів до визначення поняття «медіапростір»: сочіологічний, психологічний, журналістський, філософсько-культурний $i$ антропологічний.

Використовуючи дані сочіологічних опитувань, було з'ясовано рівень довіри громадян України до засобів масової інформації. Ми з'ясували, щзо наразі традииійні медіа активно трансформуються в цฺифрові, а мережа Інтернет набуває великої популярності.

Ми дійшли висновку, шо в умовах сьогодення відбувається зміна уявлень про соиіалізачію. Так, науковці звертають увагу на медіасоиіалізацію, яка пов'язана з руйнацією традииійних способів адаптації дитини та кризою сім '̈̈ як суспільного інституту, а період, за який відбулися зміни, щче недостатній для того, щчоб повноцінно проаналізувати наслідки і зробити чіткі висновки.

Було виокремлено низку прогалин у дослідженні поняття «медіасоиіалізація»: діяльність молоді у сучасному інформаційному просторі; медіаграмоність телевізійного перегляду й Інтернет-користування; питання використання молоддю знань відносно поводження в сучасному інформачійному просторі; необхідний рівень медіаграмонтості.

Було трунтовно розглянуто особливості інформаційної агресї̈ та методи інформаційної агресії, зокрема: дезінформування та маніпулювання; пропаганда; диверсифікаџія громадської думки; психологічний та психотропний тиск; поширення чуток.

Ключові слова: медіа, медіапростір, медіасочіалізація, медіавплив, інформаційна агресія.

Oleg CHERNYSH, orcid.org/0000-0002-4429-2020

Assistant at the Department of Journalism and Publishing,

Graduate Student at the Department of Social Pedagogy

Luhansk Taras Shevchenko National University

(Starobilsk,Luhansk region,Ukraine) chernyscholeg1995@gmail.com

\section{FEATURES OF THE PROCESS OF MEDIA SOCIALIZATION IN THE CONDITIONS OF MODERN MEDIA SPACE}

The article considers the characteristic features of modern media space and the main aspects of media socialization of the individual. Based on the analysis of psychological and pedagogical literature, we reveal the essence of the concepts of "media" and "media socialization", we use them in the study as a basis for characterizing the impact on the formation of personality. We describe the main characteristics of the post-information society.

Based on scientific research of domestic and European scientists, the concepts and features of modern media space were thoroughly analyzed. Several scientific approaches to the definition of "media space" were also identified: sociological, psychological, journalistic, philosophical, cultural and anthropological.

Using opinion polls, the level of trust of Ukrainian citizens in the media was clarified. We have found that traditional media is now being actively transformed into digital, and the Internet is gaining in popularity.

We came to the conclusion that in today's conditions there is a change in perceptions of socialization. For example, scholars point to media socialization, which is associated with the destruction of traditional ways of adapting to the child and the crisis of the family as a social institution, and the period of change is not enough to fully analyze the consequences and draw clear conclusions. 
A number of gaps in the study of the concept of "media socialization" were identified: the activities of young people in the modern information space; media literacy of television viewing and Internet use; issues of youth use of knowledge regarding behavior in the modern information space; the required level of media literacy.

The peculiarities of information aggression and methods of information aggression were thoroughly considered, in particular: misinformation and manipulation; propaganda; diversification of public opinion; psychological and psychotropic pressure; spreading rumors.

Key words: media, media space, media socialization, media influence, information aggression.

Постановка проблеми. Стрімкий розвиток інформації в сучасному світовому та українському суспільстві зумовив появу нової траєкторії суспільного руху, зміну ціннісних орієнтацій та установок. Інформація в сучасних умовах стала не тільки однією із ключових цінностей у процесі розвитку особистості, а й механізмом державотворення, важливим елементом ведення гібридних війн та засобом впливу на людські маси.

У наш час інформація, перетворившись на феномен глобального рівня, оволодіває простором і часом. Але натомість простір і час стають менш стабільними і зрозумілими, менш єдиними, більш заплутаними, непослідовними.

Однією 3 найбільш важливих особливостей суспільства інформаційної доби є те, що поряд із традиційними агентами й інститутами, такими як сім'я, референтні соціальні групи, заклади освіти, релігійні та державні установи, у процес соціалізації активно включається відносно новий, самодостатній і конкурентоспроможний соціальний агент - аудіовізуальні (екранні) медіа.

В умовах інформаційної глобалізації суспільства медіа набувають особливої ролі, впливаючи на свідомість та розвиток особистості. У зв'язку із цим дослідники виокремлюють поняття «медіасоціалізація», дослідження особливостей якого $\epsilon$ серед основних завдань сучасної наукової думку.

Аналіз досліджень. Науково-теоретичною базою для дослідження процесу медіасоціалізації особистості є наукові праці, присвячені особливостям процесу соціалізації, його чинникам, механізмам, інститутам тощо.

Так, один із класиків теорії соціалізації, А. Мудрик присвятив свої наукові твори дослідженню процесу соціалізації, доповнивши традиційні мезофактори соціалізації Інтернетом (Мудрик, 2006: 31).

Процес соціалізації особистості в умовах гібридної війни на сході України досліджують такі вчені, як: В. Курило, С. Савченко, О. Караман. Так, науковці визначили соціальні й соціальнопсихологічні особливості дітей, що стали жертвами несприятливих умов соціалізації в умовах гібридної війни на сході України.

Медіапростір як чинник побудови інформаційного суспільства розглядає Н. Голованова. Учена відзначає, що розвиток медіапростіру є складовою частиною інформаційної політики держави, проте й медіапростір визначає інформаційну політику держави.

В. Курило розглядає процес медіасоціалізації як структурний складник процесу соціалізації особистості в умовах інформаційного суспільства. У своїх наукових дослідженнях В. Курило вказує на значну роль закладів вищої освіти для успішної медіасоціалізації молоді.

О. Зінчина у своїх наукових працях розглядає й аналізує соціалізуючий вплив сучасних медіа на молодь, його позитивні та негативні наслідки. Учена доходить висновку, що сьогодні постала необхідність формування у молоді навичок медіакультури, яке б відбувалося на рівні традиційних інститутів соціалізації, зокрема сім'ї та освіти.

Проте варто зазначити, що нагальним питанням для сучасної наукової думки є осмислення практичного досвіду процесу «медіасоціалізації» та визначення шляхів його удосконалення.

Мета статті - охарактеризувати основні особливості процесу медіасоціалізації в умовах розвитку сучасного медіапростору.

Виклад основного матеріалу. Сучасний період розвитку суспільства характеризується зростанням ролі інформації як цінності для сучасної особистості XXI століття. Суспільно-політична ситуація та військові конфлікти у XX столітті продемонстрували значний вплив інформації не тільки на формування особистості, а й довели, що інформація може виступати потужним засобом впливу на людські маси.

Сьогодні науковці відзначають перехід суспільства від інформаційного (постіндустріального) до постінформаційного. Так, Н. Голованова відзначає, що наразі існує проблема розуміння сутності поняття медіапростору в сучасних умовах.

Поняття «медіапростір» набуло широкої популярності у 1980-х роках. Цей термін почали використовувати у своїх наукових працях такі учені, як: Г. Маклюен, Р. Стултс і С. Харрісон.

На теренах України в науковій думці поняття «медіапростір» 3'являється в 90-ті роки XX століття. Так, Н. Голованова визначає медіапростір як весь обсяг інформації, що циркулює в інформаційних потоках, і всі засоби трансляції інформації, 
зокрема бібліотеки, архіви, сховища, ЗМІ, засоби усної комунікації, лекторські зали університетів і академій (Голованова, 2017: 2).

Процеси, що протікають у медіапросторі, мають маніпулятивний характер, а дослідники відзначають пластичність медіапростору та його пов'язаність із соціальним простором.

Дослідниця також виділяє декілька наукових підходів до визначення поняття «медіапростір»: соціологічний, тобто сукупність засобів соціальної комунікації (П. Бергер, П. Бурдьє, Є. Гідденс, Є. Гофман, Г. Зиммель, Т. Піскун, П. Сорокін, Є. Юдіна); психологічний - сукупність засобів психологічного впливу на особистість (Ж. Бодріяр, Г. Маклюен), журналістський - сукупність засобів масової інформації та засобів масової комунікації (М. Бурич), філософсько-культурний і антропологічний - медіапростір як багатоаспектний феномен, який розглядається на різних рівнях і в різних проявах (А. Аппадураi, С. Грицай, Л. Зубанова, В. Ільганаєва, С. Кулібаба, Е. Лоренц, І. Пригожин, Д. Рашкофф, Ф. Уебстер, М. Уотерс) (Голованова, 2017: 2).

Науковці відзначають багатоаспектність поняття «медіапростір» та дають різне тлумачення цього поняття.

У своєму дослідженні ми будемо спиратися на наукові праці Н. Голованової, яка досліджувала поняття «медіапростір» як важливий чинник побудови інформаційного суспільства. Учена проаналізувала роботи учених, які також досліджували медіапростір.

Так, науковець Е. Нім у своїх дослідженнях визначає три виміри медіапростору: медійований простір, який репрезентує простір за допомогою медіа (як фізичний, так і соціальний); медіатизований простір - будь-який тип соціального простору, що передбачає використання медіа та/або відчуває ïх значний вплив, тобто це середовище поширення медійних технологій, що змінюють природу і конфігурацію самих просторів (можна говорити про медіатизацію публічного і приватного простору, політики, релігії, роботи, відпочинку, шопінгу, подорожей тощо); простір медіа («старих», «нових», їх / конвергентних форм) - матеріальний простір мас-медійних мереж і потоків (може мати як фізичну, так і «віртуальну» географію).

Якщо медійований простір співвідноситься 3 контентом, медіатизований - із середовищем його розповсюдження та споживання, то медійний простір - це канали виробництва і передачі інформації, тобто самі медіа та система їх взаємозв'язків. Межі між цими трьома вимірами досить умовні. В інформаційному суспільстві медіа втрачають свою автономність від суспіль- ства і «розпорошуються» в соціальній реальності, насичуючи іiі цифровими образами й наративами (Нім, 2013).

Як відзначають Н. Коулдрі та А. Маккарті, медіапростір - це діалектичне поняття, що відображає як медіаформи виробляють і одночасно самі виробляються існуючим соціальним простором. Крім того, це поняття, яке має кілька вимірів. 3 одного боку, медіапростір матеріальний і складається з об'єктів (приймачів, дисплеїв, кабелів, серверів, передавачів), «вбудованих» в географічно конкретні структури влади і сегменти економіки. 3 іншого боку, вже стало звичним підкреслювати «віртуальність», «примарність» і ефемерність медіапростору (особливо кіберпростору) на противагу «реальності», його віддаленість від матеріального плану існування.

Н. Кучина відзначає, що початкове призначення медіапростору - продукування та формування громадської думки, спосіб осмислення реальності, здійснення ефективної комунікації. Можна зазначити, що медіапростір - це звуження простору, яке робить світ компактним (Кучина, 2018: 152).

Останнім часом медіапростір зазнає суттєвих змін, що мають глобалізаційний характер. Складна суспільно-політична ситуація в Україні зумовила збільшення популярності ЗМІ серед громадян. Проте спостерігається зниження рівня довіри українців до вітчизняних засобів масової інформації.

Так, за результатами соціологічного опитування USAID-Internews «Ставлення населення до ЗМІ та споживання різних типів медіа у 2019 році» довіра до всіх традиційних медіа впала на $11 \%$ у порівнянні з 2018 роком.

У 2019 році довіра доЗМІ коливається між 19\% до загальнонаціональної преси, 22\% - місцевого радіо та $49 \%$ - до загальнонаціональних телеканалів.

Водночас, за даними USAID-Internews, загальнонаціональним інтернет-медіа довіряє $51 \%$ респондентів.

Також дослідники звертають увагу на те, що $68 \%$ респондентів використовують соціальні мережі для отримання новин. Це на $15 \%$ більше порівняно з 2018 роком.

За результатами дослідження спостерігається зниження популярності й охоплення аудиторії телеканалами до 6 \% порівняно з 77\% 2018 року.

Таким чином, результати проведеного опитування свідчать про те, що наразі традиційні медіа активно трансформуються в цифрові. Збільшується увага користувачів до мережі Інтернет.

У сучасних умовах традиційні 3МI також намагаються «заволодіти» аудиторією в Інтернеті. Навіть регіональні та районні видання створюють 
власні інтернет-сайти на сторінки в соціальних мережах. Ці сайти переважно є безкоштовними, але можуть бути наявний певний платний контент або рекламні матеріали.

Оскільки наразі спостерігається зростання популярності 3МI та Інтернет-мережі, науковці звертають увагу на поняття «медіасоціалізація».

На думку О. Петрунько, в сучасних умовах XXI ст. значно змінюється уявлення про соціалізацію, тому однією із провідних моделей цього процесу постає медіасоціалізація, тобто соціалізація в медіасередовищі. Учена відзначає, що медіасоціалізація наразі не має чіткого традиційного сценарію, і в цьому випадку втручання медіа у процес соціалізації можуть мати навіть агресивний характер (Тадаєва, 2013: 526).

В. Іванов та О. Волошенюк відзначають, що медіасоціалізація $€$ новим явищем інформаційного суспільства. Медіасоціалізація пов'язана з руйнацією традиційних способів адаптації дитини та кризою сім'ї як суспільного інституту, а період, за який відбулися зміни, ще недостатній для того, щоб повноцінно проаналізувати наслідки і зробити чіткі висновки.

Таким чином, можна констатувати, що медіасоціалізація послаблює реальні контакти особистості, замінюючи їх віртуальним спілкуванням. Особливо цей вплив помітний в аспекті розвитку інституту сім’ї, а отже, і реалізації традиційного механізму соціалізації.

О. Коломієць відзначає, що процес медіасоціалізації передбачає освоєння соціальних норм, але в основі лежить не позитивний досвід та навчання, a «штучний» та «чужий» досвід репрезентований за допомогою медіа.

Науковці відзначають, що в сучасних умовах необхідним є систематичний підхід до організації медіасоціалізації, який повинен починатися 3 дитинства. Але сьогодні малодослідженим $\epsilon$ процес віртуальної взаємодії.

Спираючись на дослідження А. Тадаєвої, ми визначаємо медіасоціалізацію як особливу складову частину соціалізації особистості в інформаційному просторі, яка здійснюється через нові медіа та заохочує до соціального досвіду людства кожного індивіда.

О. Петрунько зазначає, що наразі нові медіа перебирають на себе культурно-просвітницьку, освітньо-виховну й інші функції та активно витісняють традиційні інститути соціалізації за межі соціалізаційного процесу. Це пов'язано з тим, що традиційні інститути соціалізації в сучасних умовах виявляються неконкурентоспроможними.
Наразі в європейських країнах проблема медіасоціалізації є більш дослідженою. Видатний науковець Великої Британії Д. Букінгем зазначає, що наукові малодослідженими залишаються особливості впливу нових медіа на молодь. Більша увага приділяється дослідженню взаємодії у сфері особистість - Інтернет. На думку ученого, існують такі прогалини в дослідженні проблем медіасоціалізації: діяльність молоді у сучасному інформаційному просторі; медіаграмоність телевізійного перегляду й Інтернет-користування; питання використання молоддю знань відносно поводження в сучасному інформаційному просторі; необхідний рівень медіаграмонтості.

Італійський учений М. Д`Амато акцентує увагу на тому, що наразі існують певні прогалини у вихованні, зокрема молодь краще володіє навичками використання нових медіа, але не має достатнього соціального досвіду, щоб уникнути негативних аспектів медіавпливу; нові медіа нівелюють роль сім’ї; наразі недостатньо розроблені рекомендації для батьків щодо гармонізації процесу медіасоціалізації молоді в сучасному інформаційному просторі.

В Україні проблема медіасоціалізації та медіапростору набула особливої актуальності в 2014 році. Гібридна війна, що постала як наслідок анексії Криму, військово-політичної й інформаційно-психологічної анексії Росії проти України на сході нашої держави, стала однією із причин потужною інформаційної війни та, зокрема, інформаційної агресії.

На нашу думку, інформаційна агресія змінює основні характерологічні особливості медіапростору як держави-агресора, так і держави, до якої застосовується агресія.

Наразі одними 3 найпоширеніших методів інформаційної агресії $\epsilon$ : дезінформування та маніпулювання; пропаганда; диверсифікація громадської думки; психологічний та психотропний тиск; поширення чуток.

Дезінформування та маніпулювання інформацією передбачає обман чи введення об'єкта спрямувань в оману щодо справжності намірів для спонукання його до запрограмованих суб'єктом дій. Диверсифікація громадської думки має на меті роздрібнення уваги правителів держави на різноманітні штучно акцентовані проблеми. Через це відбувається відволікання уваги від вирішення першочергових завдань суспільнополітичного та економічного розвитку з метою забезпечення нормального функціонування суспільства і держави. 
Психологічний та психотропний тиск має на меті вплив на психіку особистості в результаті залякування, погроз із метою спонукання до певної запланованої моделі поведінки.

До форми психологічного тиску можна віднести: доведення до об'єкта відомостей про реальні чи нереальні загрози та небезпеки; прогнози щодо репресій, переслідувань, убивств тощо; шантажування; здійснення вибухів, підпалів, масових отруєнь, захоплення заручників, інші терористичні акції.

На особливу вагу заслуговує думка вчених щодо особливостей медіапростору в майбутньому. Так, за прогнозами деяких науковців, медіапростір майбутнього великою мірою визначатиме комунікація одинаків, що матиме як позитивні, так і негативні наслідки. Зокрема, категорію обмеженості втратить час. Необмеженими буде думка, можливість думати та зосереджуватися.

Висновки. Таким чином, медіапростір має свої як позитивні, так і негативні характерні особливості. Медіа надають можливість як для розширення, так і для звуження можливостей особистості. Сучасний медіапростір виступає інструментом у формуванні та конструюванні соціальної реальності, суспільної думки та свідомості.

Наразі особливої актуальності набуває поняття «медіасоціалізація», дослідженню якого присвятила свої наукові дослідження низка українських та європейських учених.

\section{СПИСОК ВИКОРИСТАНИХ ДЖЕРЕЛ}

1. Голованова Н. В. Медіапростір як важливий чинник побудови інформаційного суспільства. Актуальні проблеми державного управління. Теорія та історія державного управління. 2017. № 1(51). С. 1-8.

2. Кучина Н. І. Медіапростір як ареал побутування інформаційної культури. Вісник Харківської державної академії культури. 2018. № 53. С. 149-157.

3. Ним Э. Медиапространство: основные направления исследований. Бизнес. Общество. Власть. 2013. № 14. URL : https://www.hse.ru/mag/27364712/2013--14/83292427.html.

4. Петрунько О. Діти і медіа: соціалізація в агресивному медіа середовищі : монографія. Полтава : ТОВ НВП «Укрпромторгсервіс», 2010. С. 480.

5. Петрунько О. В. Деконсолідувальні ефекти медіасоціалізації. Педагогічний процес: теорія і практика. 2015. № 3-4 (48-49). C. 2-15.

6. Тадаєва А. В. Особливості соціалізації молодших школярів у сучасному інформаційному просторі. Педагогіка формування творчої особистості у вищій $і$ загальноосвітній иколах. 2013. № 33(86). С. 525-530.

\section{REFERENCES}

1. Golovanova N.V. Mediaprostir yak vazhliviy chinnik pobudovi informatsiynogo suspilstva [Media space as an important factor in building an information society]. Actual problems of public administration. Theory and history of public administration. 2017. № 1(51). Pp. 1-8. [in Ukranian].

2. Kuchina N.I. Mediaprostir yak areal pobutuvannya informatsiynoyi kulturi [Media space as an area of information culture]. Bulletin of the Kharkiv State Academy of Culture. 2018. № 53. Pp. 149-157. [in Ukranian].

3. Nim E. Mediaprostranstvo: osnovnyie napravleniya issledovaniy [Media space: main directions of research]. Business. Society. Power. 2013. № 14. URL: https://www.hse.ru/mag/27364712/2013--14/83292427.html. [in Russian].

4. Petrunko O. Diti i media: sotsializatsIya $\mathrm{v}$ agresivnomu media seredovischi [Children and media: socialization in an aggressive media environment: a monograph] : monografiya / O. Petrunko. - Poltava : Poltava: LLC SPE «Ukrpromtorgservice», 2010. - P. 480. [in Ukranian].

5. Petrunko O.V. Dekonsoliduvalni efekti mediasotsializatsiyi. [Deconsolidating effects of media socialization]. Pedagogical process: theory and practice. 2015. № 3-4 (48-49). Pp. 2-15. [in Ukranian].

6. Tadaeva A.V. Osoblivosti sotsializatsiyi molodshih shkolyariv u suchasnomu informatsiynomu prostori. [Features of socialization of junior schoolchildren in the modern information space]. Pedagogy of formation of creative personality in higher and general education schools.. 2013. № 33 (86). Pp. 525-530. [in Ukranian]. 